\title{
Studi Komparatif Tingkat Pendapatan Antara Usaha Kelapa dan Pinang pada Perkebunan Rakyat Desa Sungai Beras Kabupaten Tanjab Timur
}

\author{
Akhmadi $^{1}$, Etty Siswati ${ }^{2}$, Nurrasyidah Putri ${ }^{3}$ \\ 1,2,3 STIE-Graha Karya Muara Bulian, Jambi Indonesia \\ Correspondence email: hajiakhmadijambi@gmail.com
}

\begin{abstract}
Abstrak. Jenis penelitian yang digunakan adalah penelitian kuantitatif yaitu penelitian menggunakan data yang dinyatakan dalam bentuk angka terhadap bagian-bagian dan fenomena serta hubungan-hubungannya. Penelitian ini biasanya bertujuan untuk mengembangkan dan menggunakan model matematis, teori-teori atau hipotesis yang berkaitan dengan fenomena alam. Penelitian ini bersifat survey dan wawancara langsung kepada pemilik usaha kelapa dan pinang serta mencatat segala sesuatu yang penulis butuhkan sehubungan dengan masalah penulis teliti. Dalam penelitian ini menggunakan metode analisa data yaitu Analisis data kualitatif. Data kualitatif merupakan data yang berbentuk bukan angka melainkan dengan kata-kata yang dapat digunakan untuk menggambarkan, melengkapi dan menjelaskan serta memperkuat data kuantitatif secara langsung data dilapangan. (Sugiyono, 2011: 23). biaya produksi adalah seluruh biaya yang berhubungan dengan barang yang dihasilkan, dimana di dalamnya terdapat unsur biaya bahan baku, biaya tenaga kerja langsung dan biaya overhead pabrik. Berdasarkan jangka waktunya, produksi dibedakan menjadi jangka pendek dan jangka panjang. Dalam jangka pendek perusahaan selama masa produksinya dapat menambah salah satu faktor produksi sedangkan faktor-faktor produksi lainnya dianggap konstan. Ini artinya sebagian faktor produksi tidak dapat ditambah. Sedangkan dalam jangka panjang, perusahaan dapat merubah atau menambah semua faktor produksi yang digunakannya. Investasi awal usaha perkebunan kelapa sebesar Rp.37.004.000 yang dihitung sebelum masa produksi yaitu 7 (tujuh) tahun dan investasi awal perkebunan pinang sebesar Rp.34.750.000 yang dihitung sebelum masa produksi selama 4 (empat) tahun, untuk biaya produksi dalam satu tahun usaha perkebunan kelapa didapat sebesar Rp.5.600.000 dan biaya produksi usaha perkebunan pinang dalam satu tahun sebesar Rp.108.200.000, perbandingan antara pendapatan usaha perkebunan kelapa dan usaha perkebunan pinang didapat hasil untuk penerimaan pendapatan usaha perkebunan kelapa selama satu tahun sebesar Rp.14.400.000 dan hasil pendapatan usaha perkebunan pinang selama satu tahun sebesar Rp.110.200.000 Jadi, dapat disimpulkan bahwa pendapatan terbesar berada pada usaha pinang dibandingkan usaha kelapa .
\end{abstract}

Kata kunci: Investasi Awal, Biaya Produksi, Pendapatan dan Studi komparatif.

Abstract. This type of research is quantitative research that is research using data expressed in numerical form on parts and phenomena and their relationships. This research usually aims to develop and use mathematical models, theories or hypotheses related to natural phenomena. This research is a survey and interview directly to the owners of coconut and areca nut business and records everything that the writer needs in connection with the problem of the writer. In this study using data analysis methods, namely qualitative data analysis. Qualitative data is data in the form of not numbers but with words that can be used to describe, complete and explain and strengthen quantitative data directly in the field. (Sugiyono, 2011: 23). production costs are all costs associated with the goods produced, wherein there are elements of raw material costs, direct labor costs and factory overhead costs. Based on the time period, production can be divided into short-term and long-term. In the short term the company during its production period can add one factor of production while other factors of production are considered constant. This means that some factors of production cannot be added. Whereas in the long run, companies can change or add to all factors of production they use. The initial investment of a coconut plantation business is Rp.37,004,000 which is calculated before the production period of 7 (seven) years and the initial investment of areca nut plantation is Rp.34,750,000 which is calculated before the production period for 4 (four) years, for production costs in one the coconut plantation business year is obtained at Rp.5,600,000 and the production cost of the areca nut business in one year is Rp.108,200,000, the comparison between the coconut plantation business income and the areca nut business revenue is obtained for the income of the coconut plantation business income for one year of Rp. .14,400,000 and the results of areca nut business revenue for one year amounted to $R p$. 110,200,000 So, it can be concluded that the biggest income is in the nut business compared to the coconut business.

Keywords: Initial Investment, Production Costs, Income and Comparative Study.

\section{PENDAHULUAN}

Sektor pertanian memiliki peran penting dalam pembangunan daerah kabupaten tanjab timur khususnya di Desa Sungai Beras yang memiliki sektor perkebunan kelapa yang berkembang sejak tahun 1985. Tanaman kelapa merupakan tanaman yang ramah lingkungan karena bisa berdampingan dengan tanaman lain. Tanpa pupuk kelapa akan tetap berbuah sepanjang tahun.
Kelapa (Cocos nucifera) merupakan tanaman perkebunan berupa pohon batang lurus dari famili Palmae. Kelapa merupakan bagian yang tidak terpisahkan dari kehidupan masyarakat dengan peran yang berbeda-beda, mulai dari untuk pemenuhan kebutuhan sosial dan budaya sampai untuk kepentingan ekonomi, sehingga dijuluki tree oflife atau pohon kehidupan. 
Status yang demikian membuat bentuk usaha tani kelapa yang berkembang di masyarakat berbeda-beda pula, bergantung pada tujuan yang mendasarinya. Areal kelapa yang dimiliki oleh rakyat ini, tentunya tidak hanya tanaman kelapa saja yang ada di dalamnya melainkan ada juga tanaman sela seperti tanaman pisang dan lainnya yang berdampingan dengan tanaman kelapa itu sendiri, selain perkebunan kelapa, adapula perkebunan pinang yang berkembang sejak tahun 2002 . Tanaman pinang merupakan tanaman yang memiliki karakteristik tanaman yang berbatang lebih kecil dibandingkan tanaman kelapa, ukuran buah yang lebih kecil dan perawatannya yang hampir sama dengan tanaman kelapa serta tidak terlalu sulit. Jangka waktu penanaman pinang juga tidak memakan waktu yang lama hingga waktu panen, namun jangka waktu (umur) produksi relatif lama.

waktu panen antara usaha kelapa dan pinang berbeda, jika usaha kelapa di panen setiap tiga bulan sekali, lain halnya dengan waktu panen buah pinang yang dapat di panen satu bulan sekali. Tidak hanya itu, dari segi produktivitas memiliki perbedaan, jika produktivitas aktual perkebunan kelapa rakyat masih sangat rendah, tingkat produktivitas tanaman pinang justru lebih unggul meski sama-sama diusahakan atau dirawat secara tradisional. Namun, biaya produksi usaha kelapa terbilang lebih ekonomis.

Dalam pengelolaan usaha kelapa dan pinang pada perkebunan rakyat Desa Sungai Beras, petani sebagai produsen selalu mempertimbangkan perolehan hasil yang maksimum diantara berbagai jenis usaha yang dilakukan, namun demikian terkadang meskipun sektor usaha yang digeluti, mendatangkan hasil yang relatif rendah, tetapi masih tetap dijalankan, hal ini sematamata karena fakor penunjang (tanaman sela).

Berdasarkan uraian dari latar belakang diatas, maka penulis dapat merumuskan pokok permasalahan dalam penelitian ini adalah: 1) Berapa biaya investasi awal usaha Kelapa dan Pinang pada perkebunan Rakyat Desa Sungai Beras Kabupaten Tanjab Timur; 2) Berapa biaya produksi usaha Kelapa dan Pinang pada perkebunan Rakyat Desa Sungai Beras Kabupaten Tanjab Timur; 3) Berapa pendapatan usaha Kelapa dan Pinang pada perkebunan Rakyat Desa Sungai Beras Kabupaten Tanjab Timur.

Adapun tujuan dalam penelitian ini yang penulis ambil berdasarkan rumusan masalah di atas adalah sebagai berikut: 1) Untuk mengetahui berapa biaya investasi awal usaha Kelapa dan Pinang pada perkebunan Rakyat Desa Sungai Beras Kabupaten Tanjab Timur; 2) Untuk mengetahui berapa biaya produksi usaha Kelapa dan Pinang pada perkebunan Rakyat Desa Sungai Beras Kabupaten Tanjab Timur; 3) Untuk mengetahui pendapatan usaha Kelapa dan Pinang pada perkebunan Rakyat Desa Sungai Beras Kabupaten Tanjab Timur; 4) Untuk menganalisis studi komparatif tingkat pendapatan antara usaha Kelapa dan Pinang pada perkebunan Rakyat Desa Sungai Beras Kabupaten Tanjab Timur.

\section{METODE}

\section{Jenis Penelitian}

Jenis penelitian yang digunakan adalah penelitian kualitatif dan penelitian kuantitatif. Jenis penelitian kualitatif yaitu penelitian tentang riset yang bersifat deskriptif dan cenderung menggunakan analisis. Dalam penelitian kualitatif peneliti bertolak dari data, memanfaatkan teori yang ada sebagai bahan penjelas, dan berakhir dengan suatu "teori". Penelitian kualitatif bertujuan untuk menjelaskan fenomena dengan sedalamdalamnya melalui pengumpulan data sedalam-dalamnya.

Penelitian kuantitatif adalah suatu proses menemukan pengetahuan yang menggunakan data berupa angka sebagai alat menganalisis keterangan mengenai apa yang ingin diketahui. Tujuan penelitian kuantitatif adalah mengembangkan dan menggunakan model-model matematis, teori-teori atau hipotesis yang berkaitan dengan fenomena alam. Dalam penelitian kuantitatif, penelitian berangkat dari teori menuju data, dan berakhir pada penerimaan atau penolakan terhadap teori yang digunakan.

\section{Jenis data}

Data adalah hasil pengukuran yang bisa memberikan gambaran suatu keadaan atau memberikan suatu informasi. Adapun jenis-jenis data dibagi menjadi dua bagian, yaitu :

\section{a. Data kualitatif}

Yaitu data yang tidak dapat dianalisis dalam bentuk bilangan atau angka. Dalam penelitian, data kualitatif berupa gambaran mengenai objek penelitian dan klarifikasi mengenai suatu fenomena atau kenyataan sosial, dengan jalan mendeskripsikan sejumlah variabel yang berkenaan dengan masalah dan unit yang diteliti antara fenomena yang diuji. Tujuan dari penelitian deskriptif adalah menghasilkan gambaran akurat tentang sebuah kelompok, menggambarkan mekanisme sebuah proses atau hubungan, menyajikan informasi dasar akan suatu hubungan.

\section{b. Data kuantitatif}

Data yang dinyatakan dalam bentuk angka, yang dapat diukur atau dihitung secara langsung sebagai variabel angka atau bilangan dari perhitungan dan pengukuran yang mendeskripsikan suatu kasus atau objek penelitian.

\section{Alat Analisa}

\section{Teori Biaya Produksi}

Menurut M. Nafarin (2009:497), biaya produksi adalah seluruh biaya yang berhubungan dengan barang yang dihasilkan, dimana di dalamnya terdapat unsur 
biaya bahan baku, biaya tenaga kerja langsung dan biaya overhead pabrik. Berdasarkan jangka waktunya, produksi dibedakan menjadi jangka pendek dan jangka panjang. Dalam jangka pendek perusahaan selama masa produksinya dapat menambah salah satu faktor produksi sedangkan faktor-faktor produksi lainnya dianggap konstan. Ini artinya sebagian faktor produksi tidak dapat ditambah. Sedangkan dalam jangka panjang, perusahaan dapat merubah atau menambah semua faktor produksi yang digunakannya.

Biaya yang dikeluarkan dalam suatu perusahaan dapat dikelompokkan dalam dua kategori yaitu, biaya eksplisit dan biaya tersembunyi. Biaya eksplisit adalah pengeluaran-pengeluaran perusahaan yang berupa pembayaran dengan uang tunai untuk mendapatkan faktor-faktor produksi dan bahan baku yang dibutuhkan. Sedangkan biaya tersembunyi atau disebut juga dengan imputing cost adalah taksiran pengeluaran terhadap faktor-faktor produksi yang dimiliki perusahaan.

Menurut Soekartawi (2002) Untuk mengetahui besarnya biaya produksi yang dikeluarkan oleh petani dalam menjalankan usaha, maka dapat dihitung menggunakan rumus:

$$
\mathrm{TC}=\mathrm{TFC}+\mathrm{TVC}
$$

Dimana :

TC adalah Total Cost

TFC adalah total fixed cost

TVC adalah total variable cost

Untuk mengetahui pendapatan usaha, maka digunakan rumus sebagai berikut (Soekartawi, 2002)

$$
\mathrm{I}=\mathrm{TR}-\mathrm{TC}
$$

Keterangan:

$\begin{array}{ll}\text { I } & \text { : Income (pendapatan) } \\ \text { TR } & \text { : total rerevenue (Total Penerimaan) } \\ \text { TC } & \text { : Total Cost (Biaya Total) }\end{array}$

\section{HASIL DAN PEMBAHASAN}

Investasi Awal Usaha Kelapa dan Pinang Pada Perkebunan Rakyat Desa Sungai Beras Kabupaten Tanjab Timur

Sesuai dengan sasaran penelitian yang telah diuraikan pada bab terdahulu bahwa dalam upaya untuk mendapatkan sumber penghasilan pada umumnya masyarakat Desa Sungai Beras Kabupaten Tanjab Timur cenderung membuka usaha disektor perkebunan. Berdasarkan pertimbangan kondisi geografis serta potensi alam yang ada di wilayah Desa Sungai Beras Kabupaten Tanjab Timur dimana struktur geografis didominasi dengan kondisi lahan gambut sehingga kecenderungan masyarakat Desa Sungai Beras Kabupaten Tanjab Timur dalam menciptakan sumber penghasilan berorientasi pada penyesuaian potensi alam serta pertimbangan faktor ekonomi dari usaha yang dilakukan.

Dalam menciptakan sumber penghasilan maka ada kecenderungan masyarakat untuk berinvestasi pada kegiatan perkebunan kelapa dan pinang dari dua jenis usaha yang digeluti oleh masyarakat Desa Sungai Beras Kabupaten Tanjab Timur dirasa perlu untuk melakukan kajian seberapa besar kebutuhan investasi dalam membuka usaha baik perkebunan kelapa maupun perkebunan pinang, hal ini dilakukan guna memperoleh gambaran tentang perbandingan jumlah investasi yang dibutuhkan antara usaha perkebunan kelapa dengan usaha perkebunan pinang. Untuk lebih jelasnya berdasarkan hasil penelitian yang dilakukan melalui wawancara langsung kepada satu orang petani yang membuka usaha perkebunan kelapa dan usaha perkebunan pinang secara pribadi akan penulis uraikan dengan perhitungan sebagai berikut :

1. Investasi Awal Usaha Perkebunan Kelapa

Dalam membuka usaha perkebunan kelapa pada umumnya masyarakat Desa Sungai Beras Kabupaten Tanjab Timur memiliki lahan sendiri dengan cara membeli lahan milik warga yang tidak dikelola (lahan tinggal atau lahan terlantar) umumnya harga lahan ini bervariasi dimana tingkat harga dipengaruhi oleh posisi atau letak lahan dimaksud serta dipengaruhi juga oleh akses jalan menuju lahan yang dijadikan lahan perkebunan. Sesuai dengan salah satu tujuan dalam penelitian ini yaitu membandingkan nilai ekonomis antara usaha perkebunan kelapa dengan usaha perkebunan pinang. Dalam membuka usaha perkebunan kelapa di butuhkan komponen-komponen investasi awal yaitu sebagai berikut :

a) Pengadaan Lahan.

Berhubungan dengan investasi awal untuk perkebunan kelapa ini dibutuhkan biaya pengadaan lahan dimana tingkat harga lahan diambil secara rata-rata untuk lahan usaha perkebunan kelapa dan usaha perkebunan pinang yang cenderung memiliki standar harga yang sama dan luas yang sama yaitu $40 \mathrm{~m}$ x $250 \mathrm{~m}$ dengan tingkat harga sebesar Rp. 15.000.000. Dalam membuka usaha perkebunan kelapa lahan yang di gunakan oleh petani adalah lahan sendiri yang didapat dengan cara membeli lahan milik warga yang tidak di kelola.

b) Pengolahan Lahan

Untuk biaya pengolahan lahan umumnya memakai standar borongan dan sampai lahan siap tanam untuk ukuran $40 \mathrm{~m}$ x $250 \mathrm{~m}$ di butuhkan biaya pengolahan lahan yaitu sebesar Rp.1.500.000.

c) Pengadaan Bibit 
Dengan lahan berukuran $40 \mathrm{~m} \times 250 \mathrm{~m}$ yang telah di olah sehingga sampai pada tahap penanaman, dibutuhkan bibit kelapa sebanyak 250 bibit dengan harga satu bibit sebesar Rp.5.000 dengan umur bibit yang akan ditanam yaitu bibit yang telah tumbuh selama 2 tahun dengan tinggi 3 meter. Namun bibit yang ditanam tidak semua dapat tumbuh, ada 38 bibit kelapa yang mengalami kerusakan (tidak tumbuh) sehingga harus diganti dengan bibit yang baru dan biaya penggantian bibit sama dengan pembelian bibit pertama.

d) Penanaman

Penanaman bibit kelapa umumnya dilakukan pada saat musim hujan agar bibit tidak mudah mati atau kekeringan karena setelah penanaman bibit akan dibiarkan tumbuh tanpa disiram, oleh sebab itu dalam pembuatan usaha perkebunan kelapa membutuhkan perkiraan cuaca dan melihat kondisi iklim yang tepat. Upah tanam perbibit sebesar Rp.3.000 dan pemagaran bibit di tanggung oleh pekerja.

e) Biaya Pemeliharaan

Biaya pemeliharaan yang dihitung dalam investasi awal yaitu biaya pemeliharaan dari lahan yang sudah di tanami bibit hingga lahan berproduksi, dalam usaha perkebunan kelapa lama waktu tanaman berproduksi selama 7 (tujuh) tahun, dalam 1(satu) tahun pemeliharaan dilakukan sebanyak 4 (empat) kali dengan 1 (satu) kali pemeliharaan setiap 3 (tiga) bulan. Pemeliharaan lahan menggunakan round up sebanyak 5 (lima) liter dalam 1 (satu) kali pemeliharaan dengan harga round up Rp.65.000 perliter merk noxone.

Investasi awal :Rp.37.004.000

Terdiri dari :

- Pengadaan lahan

:Rp. 15.000 .000

- Pengolahan lahan

:Rp. 1.500 .000

- Pengadaan bibit

:Rp. 1.250 .000

- Penyisipan bibit

:Rp. $\quad 190.000$

- Upah penyisipan bibit :Rp. $\quad 114.000$

- Penanaman :Rp. $\quad 750.000$

- Biaya pemeliharaan :Rp. 9.100 .000

- Upah pemeliharaan :Rp. 9.100.000

2. Investasi Awal Usaha Perkebunan Pinang

Selain usaha perkebunan kelapa di Desa Sungai Beras juga terdapat usaha perkebunan pinang yang merupakan salah satu peluang bisnis usaha yang sangat menjanjikan, apalagi tanaman ini memiliki potensi keberhasilan yang sangat tinggi dan komoditi ekspor yang menjanjikan, usaha perkebunan pinang bisa dilakukan oleh siapa saja, selain itu cara budidaya pinang tidak terlalu sulit, begitu juga dalam melakukan perawatannya. Oleh sebab itu masyarakat Desa Sungai Beras memilih untuk melakukan usaha ini, usaha perkebunan pinang juga sangat cocok dengan kondisi tanah atau lahan gambut yang ada di Desa Sungai Beras, budidaya pinang juga tidak selalu memerlukan area yang luas selain itu pinang juga merupakan tanaman yang cocok di budidayakan di kawasan dataran rendah dan dekat dengan air. Dalam membuka usaha perkebunan pinang di butuhkan komponen-komponen investasi awal yaitu sebagai berikut :

a) Pengadaan Lahan.

Dalam membuka usaha perkebunan pinang sama halnya dengan membuka usaha perkebunan kelapa dimana lahan yang di gunakan oleh petani adalah lahan sendiri yang didapat dengan cara membeli lahan milik warga yang tidak di kelola dengan harga dan luas yang sama yaitu luas lahan $40 \mathrm{~m} \mathrm{x}$ 250 m di butuhkan biaya sebesar Rp. 15.000.000.

b) Pengolahan Lahan

Untuk investasi awal usaha perkebunan pinang juga dibutuhkan biaya pengolahan sampai lahan siap tanam dengan ukuran $40 \mathrm{~m} \times 250 \mathrm{~m}$ sebesar Rp. 1.500.000.

c) Pengadaan Bibit

Dengan lahan berukuran $40 \mathrm{~m}$ x $250 \mathrm{~m}$ yang telah di olah sehingga sampai pada tahap penanaman, dibutuhkan bibit pinang sebanyak 1.500 bibit dengan harga satu bibit sebesar Rp.3.000 umur bibit yang akan ditanam yaitu bibit yang telah tumbuh selama 1,5 tahun dengan tinggi 1 meter. Namun bibit yang di tanam tidak semua dapat tumbuh ada 70 bibit yang tidak tumbuh atau rusak dari 1.500 bibit yang di tanam, bibit yang rusak atau tidak tumbuh akan dilakukan penyisipan (penanaman ulang) dengan harga bibit yang sama.

d) Penanaman

Penanaman bibit pinang sebaiknya juga ditanam pada saat musim hujan agar bibit tumbuh dengan cepat dan baik. Upah tanam perbibit sebesar Rp.2.000 dan pemagaran bibit di tanggung oleh pekerja. Dari 1.500 bibit yang di tanam terdapat 70 bibit yang rusak dan harus di lakukan penanaman ulang dengan biaya yang sama perbibitnya.

e) Biaya Pemeliharaan

Biaya pemeliharaan pada usaha perkebunan pinang dalam investasi awal di hitung dari bibit telah di tanam hingga masa produksi yaitu selama 4 (empat) tahun, pemeliharaan lahan menggunakan round up merk noxone dengan harga satu liter sebesar Rp.65.000 sebanyak 5 liter satu kali pemeliharaan yaitu setiap 3 (tiga) bulan sekali.

f) Upah pemeliharaan

Upah pemeliharaan yang di hitung dalam investasi awal untuk usaha perkebunan pinang di Desa Sungai Beras sama dengan upah pemeliharaan usaha perkebunan pinang yaitu sebesar 
Rp.325.000 dalam satu kali pemeliharaan setiap tiga bulan sekali sebelum masa produksi selama 4 (empat) tahun.

Investasi awal

:Rp.34.750.000

Terdiri dari:

- Pengadaan lahan

:Rp. 15.000 .000

- Pengolahan lahan

:Rp. 1.500 .000

- Pengadaan bibit

:Rp. 4.500 .000

- Penanaman

:Rp. 3.000 .000

- Biaya penyisipan bibit

- Upah penyisipan

:Rp. $\quad 210.000$

- Biaya pemeliharaan

:Rp. $\quad 140.000$

- Upah pemeliharaan

:Rp. 5.200 .000

:Rp. 5.200 .000

Biaya Produksi Usaha Kelapa dan Pinang Pada Perkebunan Rakyat Desa Sungai Beras Kabupaten Tanjab Timur

Menurut Sukirno (2013:208) biaya produksi dapat didefinisikan sebagai semua pengeluaran yang dilakaukan oleh perusahaan untuk memperoleh faktorfaktor produksi dan bahan-bahan mentah yang akan digunakan untuk menciptakan barang-barang yang diproduksikan perusahaan tersebut.

1. Biaya Produksi Usaha Perkebunan Kelapa

Biaya produksi dalam usaha perkebunan kelapa yang di hitung dalam penelitian ini adalah biaya produksi dalam satu tahun setelah usaha berproduksi selama 3 (tiga) tahun karena di tahun ketiga produksi perkebunan telah menghasilkan produk dengan jumlah produksi normal. Adapun komponen - komponen biaya produksi yang dapat di hitung dalam usaha perkebunan kelapa milik rakyat ini adalah sebagai berikut :

a) Biaya Panen

Dengan tanah seluas $40 \mathrm{~m} \times 250 \mathrm{~m}$ yang berisi 250 pohon kelapa cara panen di lakukan secara tradisional dengan menggunakan sabit kelapa yang menggunakan bambu dan di lakukan oleh dua orang pekerja dengan upah pekerja di hitung berdasarkan berapa banyak kelapa yang di panen dengan harga satu buah kelapa Rp.150, berdasarkan keterangan pemilik dengan tanah seluas $40 \mathrm{~m} \times 250 \mathrm{~m}$ dengan jumlah pohon sebanyak 250 dapat menghasilkan 2.500 kelapa.

b) Biaya pengolahan produk

Pengolahan produk juga dilakukan secara tradisional dimana produk di kupas menggunakan baji (pisau pengupas) yang di lakukan oleh satu orang pekerja dengan upah Rp.100 perbuah.

c) Biaya transportasi

Produk yang telah di kupas akan di jual kepada pengepul menggunakan kendaraan air (pompong) dengan biaya angkut sebesar Rp.50 perbuah.

d) Biaya pemeliharaan

Pemeliharaan dilakukan setiap 3 (tiga) bulan sekali menggunakan round up merk noxon seharga Rp.65.000 perliter sebanyak 5 (lima) liter satu kali pemeliharaan selama satu tahun.

e) Upah pemeliharaan

Pemeliharaan usaha pekebunan dilakukan oleh satu orang pekerja dengan upah pemeliharaan sebesar Rp.325.000 dalam satu kali pemeliharaan.

Biaya produksi $\quad:$ Rp.5.600.000

Terdiri dari :

- Biaya panen :Rp.1.500.000

- Biaya pengolahan :Rp.1.000.000

- Biaya transportasi :Rp. 500.000

- Biaya pemeliharaan :Rp.1.300.000

- Upah pemeliharaan :Rp.1.300.000

2. Biaya Produksi Usaha Perkebunan Pinang

Biaya produksi dalam usaha perkebunan pinang yang di hitung dalam penelitian ini adalah biaya produksi dalam satu tahun setelah usaha berproduksi selama 2 (dua) tahun karena di tahun kedua produksi perkebunan telah menghasilkan produk dengan jumlah produksi normal. Adapun komponen - komponen biaya produksi yang dapat di hitung dalam usaha perkebunan pinang milik rakyat ini adalah sebagai berikut :

a) Biaya Panen

Dengan tanah seluas $40 \mathrm{~m} \times 250 \mathrm{~m}$ yang berisi 1.500 pohon pinang cara panen di lakukan secara tradisional dengan menggunakan sabit pinang yang menggunakan bambu dan di lakukan oleh dua orang pekerja dengan upah pekerja di hitung satu karung pinang sebesar Rp.15.000 hingga pinang siap untuk di angkut. Berdasarkan keterangan pemilik dengan tanah seluas $40 \mathrm{~m} \mathrm{x}$ $250 \mathrm{~m}$ dan jumlah pohon sebanyak 1.500 dapat menghasilkan 200 karung pinang dalam satu kali panen dengan waktu panen satu bulan sekali. Di dalam proses panen memerlukan karung panen sebanyak 200 dengan harga satu karung panen Rp.3.000 yang di sediakan oleh pemilik usaha perkebunan yang memiliki nilai pakai selama 3 (tiga) bulan.

b) Biaya transportasi

Produk yang telah dipanen akan di angkut menggunakan kendaraan air (pompong) dari kebun hingga sampai di rumah pemilik dengan upah angkut Rp.2.000 perkarung.

c) Biaya pengolahan produk

Pengolahan produk dilakukan secara tradisional dimana produk di kupas menggunakan parang (pisau pengupas) secara manual dengan upah sebesar Rp.2.000 perkilo dengan kondisi pinang yang masih basah (belum dijemur). Dengan jumlah 200 karung pinang setelah dikupas menghasilkan $2.600 \mathrm{~kg}$ pinang basah yang langsung di jual kepada pengepul (tokeh). 
Akhmadi et al, Studi Komparatif Tingkat Pendapatan Antara Usaha Kelapa dan Pinang pada Perkebunan Rakyat Desa Sungai Beras Kabupaten Tanjab Timur

d) Biaya pemeliharaan

Pemeliharaan dilakukan setiap 3 (tiga) bulan sekali menggunakan round up merk noxon seharga Rp.65.000 perliter sebanyak 5 (lima) liter satu kali pemeliharaan selama satu tahun.

e) Upah pemeliharaan

Pemeliharaan usaha pekebunan dilakukan oleh satu orang pekerja dengan upah pemeliharaan sebesar Rp.325.000 dalam satu kali pemeliharaan. Biaya produksi

:Rp.108.200.000

Terdiri dari :

- Biaya panen

:Rp.36.000.000

- Biaya Karung panen

:Rp 2.400 .000

- Biaya transportasi

- Biaya pengolahan

- Biaya pemeliharaan

:Rp. 4.800 .000

:Rp.62.400.000

:Rp. 1.300 .000

- Upah pemeliharaan

Pendapatan Usaha Kelapa dan Pinang Pada Perkebunan Rakyat Desa Sungai Beras Kabupaten Tanjab Timur

Pendapatan merupakan suatu unsur yang harus dilakukan dalam melakukan suatu usaha, karena dalam melakukan suatu usaha tentu ingin mengetahui nilai atau jumlah pendapatan yang diperoleh selama melakukan usaha. Pendapatan sangat berpengaruh bagi kelangsungan suatu usaha, semakin besar pendapatan yang diperoleh maka semakin besar kemampuan suatu usaha untuk membiayai segala pengeluaran dan kegiatan-kegiatan yang akan dilakukan. Kondisi usaha dapat diukur dengan menggunakan konsep pendapatan yang menunjukan jumlah seluruh uang yang diterima oleh pemilik usaha selama jangka waktu tertentu.

1. Pendapatan Usaha Kelapa

Untuk mengetahui berapa jumlah pendapatan usaha perkebunan kelapa rakyat di Desa Sungai Beras disini peneliti akan menghitung pendapatan usaha perkebunan kelapa selama satu tahun yaitu pada tahun ketiga usaha berproduksi karena di tahun ketiga usaha kelapa telah diproduksi secara normal dibandingkan tahun pertama dan tahun kedua. Untuk produk yang dihasilkan oleh usaha perkebunan kelapa selama satu tahun sebanyak 10.000 produk dengan harga satu produk Rp.2.000 dari seluruh pendapatan akan dikurangi dengan total biaya produksi selama satu tahun sebesar Rp. Rp.5.600.000 Komponen perhitungan pendapatan usaha kelapa sebagai berikut :

- Hasil panen dalam satu tahun

- Harga jual perbuah

- $10.000 \times 2000$

$: 10.000$ produk

:Rp. 2.000

$=20.000 .000$;
Rumus :

$\mathrm{I}=\mathrm{TR}-\mathrm{TC}$

$\mathrm{I}=\mathrm{Rp} \cdot 20.000 .000-\mathrm{Rp} \cdot 5 \cdot 600.000=14.400 .000(1$ tahun)

2. Pendapatan Usaha Pinang

Untuk mengetahui berapa jumlah pendapatan usaha perkebunan pinang rakyat di desa sungai beras, peneliti akan menghitung pendapatan usaha perkebunan pinang selama satu tahun yaitu pada tahun kedua usaha berproduksi. Untuk produk yang dihasilkan oleh usaha perkebunan pinang selama satu tahun sebanyak 31.200 kilo pinang yang sudah di kupas dalam keadaan basah (tidak dijemur) dengan harga satu kilo produk Rp.7.000 dari seluruh pendpatan akan dikurangi dengan total biaya produksi selama satu tahun sebesar Rp. Rp. 108.200.000.

Komponen perhitungan pendapatan usaha pinang sebagai berikut :

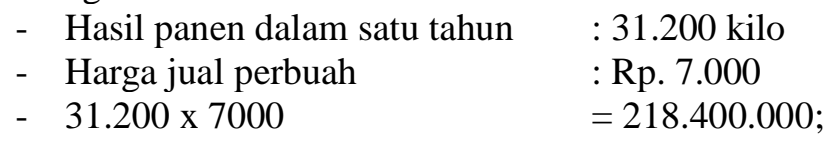

Rumus

$$
\mathrm{I}=\mathrm{TR}-\mathrm{TC}
$$

I : Income(pendapatan)

$\mathrm{I}=\mathrm{Rp} .218 .400 .000-\mathrm{Rp} .108 .200 .000=$ Rp.110.200.000 (1 tahun)

Analisis Studi Komparatif Tingkat Pendapatan Antara Usaha Kelapa dan Pinang Pada Perkebunan Rakyat Desa Sungai Beras Kabupaten Tanjab Timur

Studi komparatif memiliki arti yang bersifat membandingkan. Dalam penelitian komparatif merupakan penelitian yang sifatnya membandingkan, yang dilakukan untuk membandingkan persamaan dan perbedaan atau keunggulan dan kekurangan dua atau lebih sifat-sifat dan fakta-fakta objek yang diteliti berdasarkan suatu kerangka pemikiran tertentu. Analisis komparatif dalam penelitian ini adalah untuk membandingkan tingkat pendapatan antara usaha kelapa dan pinang pada perkebunan rakyat Desa Sungai Beras Kabupaten Tanjab Timur.

Berdasarkan hasil penelitian diatas, dapat di simpulkan bahwa perbandingan tingkat pendapatan antara usaha kelapa dan pinang pada perkebunan rakyat desa Sungai Beras Kabupaten Tanjab Timur adalah sebagai berikut :

Tabel 1. Perbandingan Investasi Awal, Biaya Produksi dan Pendapatan Antara Usaha Kelapa Dan Pinang Pada Perkebunan Rakyat Desa Sungai Beras Kabupaten Tanjab Timur

\begin{tabular}{cccc}
\hline No & Jenis Perbandingan & Usaha Kelapa & Usaha Pinang \\
\hline 1. & Investasi Awal & Rp.37.004.000 & Rp.34.750.000 \\
2. & Biaya Produksi & Rp.5.600.000 & Rp.108.200.000 \\
3. & Pendapatan & Rp. 14.400 .000 & Rp.110.200.000 \\
\hline
\end{tabular}


Dari tabel diatas dapat di uraikan bahwa investasi awal usaha perkebunan kelapa sebesar Rp.37.004.000 yang dihitung sebelum masa produksi yaitu 7 (tujuh) tahun dan investasi awal perkebunan pinang sebesar Rp.34.750.000 yang dihitung sebelum masa produksi selama 4 (empat) tahun, untuk biaya produksi dalam satu tahun usaha perkebunan kelapa didapat sebesar Rp.5.600.000 dan biaya produksi usaha perkebunan pinang dalam satu tahun sebesar Rp. 108.200.000, perbandingan antara pendapatan usaha perkebunan kelapa dan usaha perkebunan pinang didapat hasil untuk penerimaan pendapatan usaha perkebunan kelapa selama satu tahun sebesar Rp.14.400.000 dan hasil pendapatan usaha perkebunan pinang selama satu tahun sebesar Rp. 110.200.000. Jadi, dapat disimpulkan bahwa pendapatan terbesar berada pada usaha pinang dibandingkan usaha kelapa.

\section{SIMPULAN}

Dari hasil penelitian dan pembahasan tentang studi komparatif tingkat pendapatan antara usaha kelapa dan pinang pada perkebunan rakyat Desa Sungai Beras Kabupaten Tanjab Timur maka terdapat beberapa pokok kesimpulan yaitu sebagai berikut :

1. Investasi awal usaha kelapa pada perkebunan rakyat Desa Sungai Beras Kabupaten Tanjab Timur adalah sebesar Rp.37.004.000 dan investasi awal usaha pinang pada perkebunan rakyat Desa Sungai Beras Kabupaten Tanjab Timur adalah sebesar Rp. 34.750.000.

2. Biaya produksi pada usaha kelapa desa Sungai Beras Kabupaten Tanjab Timur didapat biaya produksi selama satu tahun sebesar Rp. 5.600 .000 dan biaya produksi usaha pinang selama satu tahun sebesar Rp. 108.200.000

3. Pendapatan pada usaha kelapa Desa Sungai Beras Kabupaten Tanjab Timur diperoleh hasil pendapatan dengan 4 (empat) kali panen selama satu tahun sebesar Rp. 14.400.000 dan hasil pendapatan pada usaha pinang dengan 12 (dua belas) kali panen selama satu tahun sebesar Rp. 110.200.000.

4. Analisis studi komparatif antara usaha kelapa dan pinang pada perkebunan rakyat Desa Sungai Beras Kabupaten Tanjab Timur didapat hasil pendapatan tertinggi berada pada usaha pinang dalam satu tahun. Sebesar Rp. 110.200.000 sedangkan pendapatan usaha kelapa selama satun tahun sebesar Rp. 14.400.000.

\section{DAFTAR PUTAKA}

Arikunto. 2010. Prosedur Penelitian Suatu Pendekatan Praktik. Jakarta :Rineka Cipta.

Fahmi, Irham. 2012. Analisis Laporan Keuangan. Bandung. Alfabeta.
Heizer, dan Barry Reider. 2011. Manajemen operasi. Diterjemahkan oleh Chriswan Sungkono. Jakarta :Salemba Empat.

Jogiyanto, H.M. 2010. Teori Portofolio dan Analisis Investasi. Yogyakarta :BPFE

Kasmir, dan Jakfar. 2012. Studi Kelayakan Bisnis. Jakarta :Kencana.

Kieso, Weygant, dan Warfield. 2011. Akuntansi Intermediate. Jakarta :Erlangga.

Martalena, dan Malinda. 2011. Pengantar Pasar Modal. Yogyakarta :Alfabeta.

Muana, Nanga. 2010. Makro Ekonomi. Jakarta : PT. Raja GrafindoPersada.

Nazir, Moh. 2005. Metode Penelitian. Jakarta :Ghalia Indonesia.

Samuelson, dan William D Nordhaus. 2013. Mikro Ekonomi.Jakarta :Erlangga.

Soekartawi, 2002.Analisis usaha tani.Jakarta :Universitas Indonesia.

Stice, K. Fred Skousen. 2011. Akuntansi Keuangan. Jakarta :SalembaEmpat.

Sudana. 2011. Manajemen Keuangan. Jakarta : Raja GrafindoPersada.

Sugiyono.2014. Metode Penelitian Pendidikan Pendekatan Kuantitatif, Kualitatif. Bandung :Alfabeta.

Suroto. 2000. Strategi pembangunan dan perencanaan kesempatan kerja "pendapatan". Yogyakarta :Universitas Gajah Mada.

Tandelin, Eduardus. 2010. Analisis Investasi dan Manajemen Portofolio. Yogyakarta : BPFE.

http://www.agrowindo.com/peluang-usaha-budidayapinang-dan-analisa- usahanya.htm 